\title{
Feeding ecology of the marine cladoceran Penilia avirostris: natural diet, prey selectivity and daily ration
}

\author{
Dacha Atienza*, Enric Saiz, Albert Calbet \\ Institut de Ciències del Mar-CMIMA (CSIC), Ps. Marítim de la Barceloneta 37-49, 08003 Barcelona, Spain
}

\begin{abstract}
Penilia avirostris is an important component of the mesozooplankton of shelf waters during the stratification period. This study investigates the feeding ecology of $P$. avirostris under natural dietary conditions in the NW Mediterranean during their summer appearance. The results indicate that $P$. avirostris feeds on particles in a wide size range, mostly on nanoplankton ( 2 to $20 \mu \mathrm{m})$, including larger prey such as dinoflagellates and ciliates. Autotrophic and heterotrophic bacteria were not grazed on, but picoflagellates $(<2 \mu \mathrm{m})$ were significant contributors to diet, indicating a narrow threshold of lower prey size. Ciliates were cleared at low rates which, at times, were not significant, probably because of their ability to escape feeding currents. Although this marine cladoceran is considered to behave like a filter feeder, our results indicate that it can display variable selectivity patterns that do not only depend on prey size. During the strict oligotrophic conditions that were present in summer NW Mediterranean waters, daily rations of $P$. avirostris averaged $82 \%$ body $\mathrm{C} \mathrm{d}^{-1}$ (range: 26 to $157 \%$ ). Such feeding rates seem to be an adaptation to allow them to succeed under low food conditions and outcompete other components of the marine zooplankton, such as copepods.
\end{abstract}

KEY WORDS: Penilia avirostris · Natural diet · Grazing rates · Selectivity · Nanoflagellates · Diatoms · Dinoflagellates · Ciliates

\section{INTRODUCTION}

The ecological role of any organism is determined by its position and significance in food webs. Decisive characteristics are body size, food spectrum and feeding strategies. Feeding is one of the most important processes for zooplankton because it supplies the requirements to maintain its production and activity. Also, it is the main route for the transfer of energy and matter from lower to higher trophic levels (Valiela 1995, Båmstedt et al. 2000). Therefore, in order to understand the dynamics of pelagic food webs, it is important to know how consumers select their food and at what rate they ingest prey.

Classically, most of the studies on feeding rates and the factors controlling them in marine planktonic systems have concentrated on copepods, the major component of the mesozooplankton. However, in recent decades, other groups like appendicularians, ctenophores, or medusae have received more atten- tion, because of their relevance to food web dynamics (López-Urrutia et al. 2003, González et al. 2004, Maar et al. 2004). In the present study we focus on one of these other groups, the marine cladocerans.

In contrast to freshwaters, where cladocerans are the dominant mesozooplanktonic group, with $>600$ species recorded, cladocerans have not been ecologically successful in the marine environment (there are only 8 true marine species; Egloff et al. 1997). According to this low diversity and the overall low abundance found in the oceans, especially in cold and highlatitude ecosystems, cladocerans have been commonly neglected in marine autoecological studies. However, marine cladocerans can, in fact, build up a large fraction of the zooplankton standing stock in many coastal and even oceanic environments on a seasonal basis, and probably, on these occasions, play a major role in the dynamics of planktonic food webs (Turner et al. 1988, Kim et al. 1989). Of all marine cladocerans, only one species has been described as a true filter feeder, 
the sidid Penilia avirostris, which inhabits near-shore waters of tropical and warm-temperate areas all over the world (Della Croce 1964, Onbé 1985, Onbé \& Ikeda 1995, Calbet et al. 2001, Marazzo \& Valentin 2001).

Only a few studies have reported on the feeding of Penilia avirostris (e.g. Paffenhöffer \& Orcutt 1986, Turner et al. 1988, 1998, Katechakis \& Stibor 2004). Among those, to our knowledge, no studies encompassing the whole spectrum of naturally occurring autotrophic and heterotrophic prey types have been conducted to characterise the feeding ecology of this cladoceran. This lack of information has made it difficult to establish the relevance of $P$. avirostris in marine planktonic communities. Here, as part of a series of studies focused on the ecological role of $P$. avirostris in marine food webs, we investigated the feeding rates of $P$. avirostris under a broad range of natural diets during their seasonal peak of abundance and determined their prey size spectrum. Our aim was to describe the dietary-composition and prey-selectivity patterns of this cladoceran on different components of the microbial community and to establish the variation in their food uptake as a function of prey availability.

\section{MATERIALS AND METHODS}

We conducted 8 grazing experiments at either of 2 stations located in coastal waters (ca. 1 mile from coast) off Masnou and Barcelona (Spain) during the summers of 2002 and 2003. Both sampling sites have similar characteristics and constitute shallow waters on the open coast. Further details on hydrographic characteristics and zooplankton composition are found in Cebrián et al. (1996) and Calbet et al. (2001).

Water for experiments was collected at $1 \mathrm{~m}$ depth with a transparent hydrographic bottle and transported to the laboratory within $1 \mathrm{~h}$. The water was gently poured into a $50 \mathrm{l}$ bucket and reverse-flow filtered by gently submerging a $30 \mathrm{~cm}$ diameter polyvinyl chloride cylinder fitted with a $100 \mu \mathrm{m}$ mesh bottom. Once the prey suspension was ready, it was amended with a nutrient mixture $\left(15 \mu \mathrm{M} \mathrm{NH} \mathrm{NH}_{4} \mathrm{Cl}\right.$ and $1 \mu \mathrm{M} \mathrm{Na}_{2} \mathrm{HPO}_{4}$ ) to compensate for nutrient enrichment due to zooplankton excretion.
Penilia avirostris were collected by short oblique net tows with a Juday-Bogorov net $(200 \mu \mathrm{m}$ mesh, $40 \mathrm{~cm}$ diameter) fitted with a 51 plastic bag as the cod end. Once on board, the bag mouth was tied with a string to prevent $P$. avirostris from sticking to the air-water interface. The samples were transported to the laboratory in an isothermic container within $1 \mathrm{~h}$ of collection.

The experiments consisted of incubations in Pyrex bottles (625 ml for experiments during 2002; $1200 \mathrm{ml}$ for experiments during 2003), filled with the natural microbial community $(<100 \mu \mathrm{m})$ and added grazers Penilia avirostris for the experimental treatments. Groups of $P$. avirostris were sorted with a widemouthed pipette under the stereomicroscope and placed in the experimental bottles (33 ind. $\mathrm{l}^{-1}$ ). In total, 4 experimental bottles and 4 control bottles (without grazers) were incubated for $24 \mathrm{~h}$ on a plankton wheel (0.2 rpm) in a temperature-controlled room at in situ temperature and photoperiod (Table 1). Three additional bottles were used to determine the initial prey concentrations. After incubation, the water was gently poured through a $135 \mu \mathrm{m}$ sieve to collect the grazers, which were checked for activity and preserved with formalin (4\% final concentration).

The microbial components analysed in the grazing experiments were heterotrophic bacteria, Prochlorococcus, Synechococcus, pico- and nanoflagellates $(<2$, 2 to 5 and $>5 \mu \mathrm{m}$ ), dinoflagellates, diatoms (single and in chains) and ciliates.

Samples $(2 \mathrm{ml}$ ) for heterotrophic bacteria Prochlorococcus and Synechococcus were preserved in paraformaldehyde + glutaraldehyde $(1+0.05 \%$ final concentrations, respectively) and stored at $-80^{\circ} \mathrm{C}$ until analysis. Flow cytometry analysis was conducted with a FACScalibur flow cytometer following the procedures in Gasol \& del Giorgio (2000). Heterotrophic bacteria biomass was estimated from volume determinations $(V)$ using the relationship $\mu \mathrm{g} C=0.12 V^{0.7}$ (Norland 1993). Prochlorococcus and Synechococcus biomasses were determined after assuming a carbon content of $0.123 \mathrm{pg} \mathrm{C} \mathrm{m}^{-3}$ and equivalent spherical diameters (ESD) of, respectively, 0.60 and $1.0 \mu \mathrm{m}$ (Waterbury et al. 1986).

For the assessment of pico- and nanoflagellate abundance, samples were preserved with glutaralde-

Table 1. Experimental conditions and carbon content (ind.$^{-1}$; mean $\pm \mathrm{SE}$ ) of the cladocerans incubated in the experiments conducted

\begin{tabular}{|lcccccccc|}
\hline & Expt 1 & Expt 2 & Expt 3 & Expt 4 & Expt 5 & Expt 6 & Expt 7 & Expt 8 \\
\hline Date $(\mathrm{dd} / \mathrm{mm} /$ yy) & $23 / 07 / 02$ & $14 / 08 / 02$ & $04 / 09 / 02$ & $26 / 09 / 02$ & $22 / 07 / 03$ & $29 / 07 / 03$ & $07 / 08 / 03$ & $12 / 08 / 03$ \\
Temperature in situ $\left({ }^{\circ} \mathrm{C}\right)$ & 24.2 & 23.8 & 23.1 & 22.0 & 26.5 & 25.5 & 26.1 & 27.1 \\
Temperature incubation $\left({ }^{\circ} \mathrm{C}\right)$ & 23.8 & 23.0 & 23.3 & 22.0 & 25.8 & 25.5 & 26.8 & 27.1 \\
Body mass $\left(\mu \mathrm{g} \mathrm{C}\right.$ ind ${ }^{-1}$ ) & 0.57 & 0.70 & 0.60 & 0.84 & 0.67 & 0.49 & 0.50 & 0.50 \\
& $(0.06)$ & $(0.07)$ & $(0.01)$ & $(0.03)$ & $(0.05)$ & $(0.02)$ & $(0.01)$ & $(0.02)$ \\
\hline
\end{tabular}


hyde ( $1 \%$ final concentration) for 3 to $6 \mathrm{~h}\left(4^{\circ} \mathrm{C}\right.$ in dark), filtered onto $0.8 \mu \mathrm{m}$ black polycarbonate membrane filters and stained with DAPI (4',6-diamidino2-phenylindole; $5 \mu \mathrm{g} \mathrm{ml}^{-1}$ final concentration) (Porter \& Feig 1980). At least 300 cells were counted and classified according to size $(<2,2$ to 5 and $>5 \mu \mathrm{m})$ using epifluorescence microscopy (Olympus BX40). For the $<2 \mu \mathrm{m}$ fraction, a nominal size of $2 \mu \mathrm{m}$ was assumed; for the other 2 categories, 40 cells were measured in each case. The carbon per cell was estimated using a factor of $0.22 \mathrm{pg} \mathrm{C} \mathrm{\mu m}^{-3}$ (Børsheim \& Bratbak 1987).

For the determination of dinoflagellate, diatom and ciliate concentrations, $200 \mathrm{ml}$ samples were preserved with $1 \%$ acidic Lugol's solution. In 2003 we became aware of a potential source of ciliate losses due to the sieving of water to collect Penilia avirostris at the end of the experiments prior to withdrawing the samples. We conducted an additional experiment to investigate the effects of this standard procedure by comparing it with gentle, direct siphoning into the preservation bottles. Significant differences were found between treatments (aloricated ciliates: unsieved $=1.20 \pm$ $0.01 \mathrm{SE}$, sieved $=0.79 \pm 0.01 \mathrm{SE}$; loricated ciliates: unsieved $=2.92 \pm 0.01 \mathrm{SE}$, sieved $=2.02 \pm 0.07 \mathrm{SE}$; 1 -way ANOVA, p < 0.05), the sieving process reducing the ciliate abundance by ca. $30 \%$. Because of this result, samples were gently siphoned directly into bottles containing the required dose of acidic Lugol's. Data belonging to previous experiments (2002) were corrected accordingly. Ciliate abundance (in all experiments) was further increased by a factor of $30 \%$ to correct for losses due to Lugol's preservation (Broglio et al. 2004, Calbet \& Saiz 2005). Then, $100 \mathrm{ml}$ aliquots were allowed to settle in Utermöhl chambers and counted in their entirety with an inverted microscope. Digital pictures of at least 60 cells of each type were taken and sized. Cell volumes were converted into car-

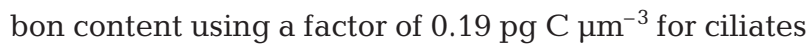
(Putt \& Stoecker 1989), the equation $\log \left(\mathrm{pg} \mathrm{C} \mathrm{cell}^{-1}\right)=$ $0.811(\log V)-0.541$ for diatoms and the equation $\log$ $\left(\right.$ pg C cell $\left.{ }^{-1}\right)=0.819(\log V)-0.119$ for dinoflagellates (Menden-Deuer \& Lessard 2000).

The relation between body length $(L)$ and dry weight $(D W)$ of Penilia avirostris was also determined. Groups (10 to 15) of similar-sized individuals were measured from the tip of the head to the base of the caudal setae (Uye 1982), placed on pre-combusted and preweighed aluminium caps and dried at 55 to $60^{\circ} \mathrm{C}$ for $24 \mathrm{~h}$. Dry weight measurements $(\mu \mathrm{g})$ were made on an ATI CAHN C-35 microbalance. Fig. 1 shows the relationship between size and biomass for P. avirostris. The fitted equation was used to estimate the biomass of cladocerans in the grazing experiments. Carbon content was assumed to be $50 \%$ of dry weight (Uye 1982).

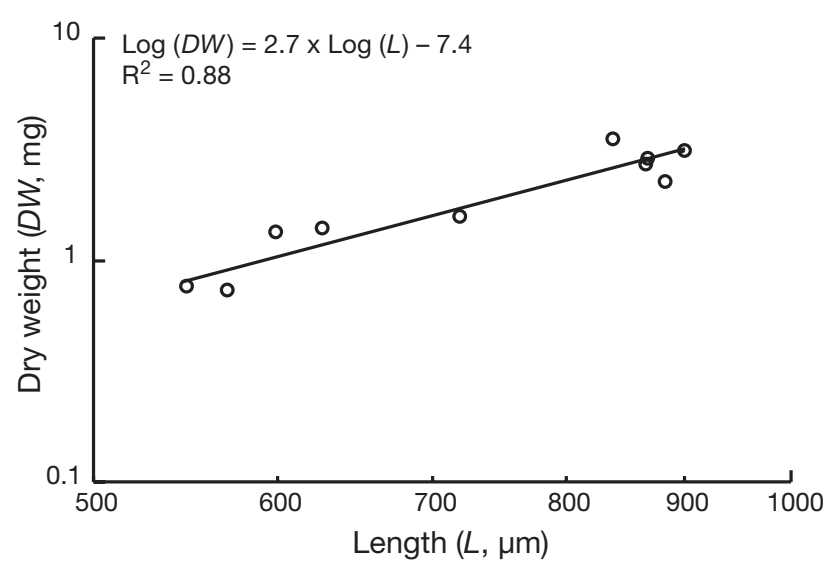

Fig. 1. Penilia avirostris. Length-dry weight relationship

Clearance and ingestion rates were calculated for each prey type according to Frost (1972), after verification that prey growth rates in grazing bottles were significantly different and lower than in the controls (1-way ANOVA, 2-tailed $\mathrm{p}<0.05)$. Bacterial growth rates were never decreased by the presence of Penilia avirostris, in fact, on occasion, they were enhanced.

Clearance rates for diatoms were computed separately for single cells and those in chains. Diatom chains were not very long, ranging between 2 to 3 and 6 cells chain ${ }^{-1}$. To take into account potential changes in chain length after grazing activity, clearance rates were computed based on the number of cells per chain at the start and end of the incubations. This procedure warranted the computation of actual ingestion rates.

Selectivity patterns of Penilia avirostris were determined through the normalised selectivity coefficient $W^{\prime}$ (Vanderploeg 1994). This coefficient was calculated from clearance rates $\left(F_{i}\right)$ for the different groups of $i$ prey as $W_{i}^{\prime}=F_{i} / F_{\text {pref }}$, where $F_{\text {pref }}$ is the clearance rate for the preferred prey (i.e. maximum clearance rate observed in the incubation). By definition, preferred prey have a selectivity coefficient of $W_{\text {pref }}^{\prime}=1$, whereas non-eaten prey have $W_{i}^{\prime}=0$. This selectivity index is independent of both the number of prey and the prey type included in the analysis (Vanderploeg 1994). The selectivity coefficients were computed within each experiment based on the average clearance values (between replicate bottles) for each prey considered. In order to determine the $F_{\text {pref }}$ in an experiment, we initially conducted a Hsu's test for the 'best' (significance level 0.05, after previous ANOVA test; Hsu 1981) for finding the maximum clearance rates exhibited by $P$. avirostris for each prey type in that experiment. According to the results of the Hsu tests, all prey items, which were cleared at maximal rates, were allocated a selectivity coefficient of 1. 


\section{RESULTS}

Table 2 shows the initial microbial community of each experiment. In terms of biomass, heterotrophic bacteria dominated the microbial community, with concentrations ranging between 17.6 and $122.2 \mu \mathrm{g} \mathrm{C}$ $\mathrm{l}^{-1}$. Medium (2 to $\left.5 \mu \mathrm{m}\right)$ and large $(>5 \mu \mathrm{m})$ sized flagellates were the next most important contributors (respectively, 3.6 to 15.5 and 4.3 to $29.1 \mu \mathrm{g} \mathrm{C} \mathrm{l}^{-1}$ ). Dinoflagellates, diatoms and ciliates were the lowest contributors to the bulk of plankton, with some excep- tions (Expt 5 and Expt 6, chain-forming diatoms). Total community biomass ranged between 49.2 and $208.4 \mathrm{\mu g}$ $\mathrm{C}^{-1}$. Clearance rates of Penilia avirostris were highly variable and covered a broad prey size spectrum, ranging from $<2 \mu \mathrm{m}$ up to $30 \mu \mathrm{m}$ ESD (Table 3). Autotrophic and heterotrophic bacteria were not grazed upon in any of the experiments (in some incubations they were even significantly enhanced). Regarding the other components of the microbial community, flagellates (the 3 size classes) were regular components of the diet, with clearance rates ranging

Table 2. Initial size (equivalent spherical diameter $[\mathrm{ESD}], \mu \mathrm{m})$, abundance (Abund, cells $\mathrm{ml}^{-1}$ ) and biomass $\left(\mu \mathrm{g} \mathrm{Cl^{-1 }}\right.$ ) of the different components of the microbial community. Abundance of heterotrophic bacteria $\left(\right.$ HetBact $\left._{i} \times 10^{6}\right)$ (total biomass: accumulated

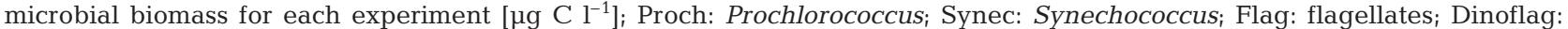
dinoflagellates; Single-Diat: single diatoms; Chain-Diat: chain-forming diatoms; Avg.: mean values [ $\pm \mathrm{SE}]$ )

\begin{tabular}{|c|c|c|c|c|c|c|c|c|c|}
\hline & Expt 1 & Expt 2 & Expt 3 & Expt 4 & Expt 5 & Expt 6 & Expt 7 & Expt 8 & Avg. \\
\hline \multicolumn{10}{|l|}{ HetBact } \\
\hline ESD & 0.51 & 0.51 & 0.52 & 0.54 & 0.54 & 0.50 & 0.51 & 0.52 & $0.52(0.01)$ \\
\hline Abund. & 1.00 & 0.87 & 1.73 & 0.72 & 2.33 & 0.67 & 0.41 & 0.25 & $0.99(0.24)$ \\
\hline Biomass & 41.2 & 17.6 & 24.7 & 22.9 & 122.2 & 42.1 & 21.6 & 20.7 & $39.1(12.32)$ \\
\hline \multicolumn{10}{|l|}{ Proch } \\
\hline ESD & 0.60 & 0.60 & 0.60 & 0.60 & 0.60 & 0.60 & 0.60 & 0.60 & $0.60^{\mathrm{a}}$ \\
\hline Abund. & 7533 & 2577 & 10937 & 8983 & 188 & 514 & 8051 & 1123 & 4988 (1530) \\
\hline Biomass & 0.10 & 0.04 & 0.15 & 0.12 & 0.003 & 0.01 & 0.11 & 0.02 & $0.1(0.02)$ \\
\hline \multicolumn{10}{|l|}{ Synec } \\
\hline ESD & 1.00 & 1.00 & 1.00 & 1.00 & 1.00 & 1.00 & 1.00 & 1.00 & $1.00^{\mathrm{a}}$ \\
\hline Abund. & 95983 & 70000 & 39139 & 43252 & 17238 & 30535 & 29442 & 35928 & 45190 (9029) \\
\hline Biomass & 6.2 & 4.5 & 2.5 & 2.8 & 1.1 & 2.0 & 1.9 & 2.3 & $2.9(0.58)$ \\
\hline \multicolumn{10}{|l|}{$<2 \mu \mathrm{m}$ Flag } \\
\hline ESD & 2.0 & 2.0 & 2.0 & 2.0 & 2.0 & 2.0 & 2.0 & 2.0 & $2.00^{\mathrm{a}}$ \\
\hline Abund. & 3706 & 3850 & 1955 & 4770 & 6809 & 4710 & 3764 & 3644 & $4151(487)$ \\
\hline Biomass & 3.4 & 3.5 & 1.8 & 4.4 & 6.3 & 4.3 & 3.5 & 3.4 & $3.8(0.45)$ \\
\hline \multicolumn{10}{|l|}{$2-5 \mu \mathrm{m}$ Flag } \\
\hline ESD & 4.1 & 3.7 & 3.8 & 3.9 & 3.9 & 3.8 & 3.6 & 3.7 & $3.82(0.02)$ \\
\hline Abund. & 808 & 2298 & 553 & 1106 & 2190 & 2408 & 1906 & 1896 & $1646(254)$ \\
\hline Biomass & 6.2 & 13.2 & 3.6 & 7.4 & 14.8 & 15.5 & 10.3 & 11.5 & $10.3(1.51)$ \\
\hline \multicolumn{10}{|l|}{$>5 \mu \mathrm{m}$ Flag } \\
\hline ESD & 8.2 & 8.0 & 7.7 & 8.7 & 8.0 & 7.6 & 7.9 & 7.5 & $7.94(0.06)$ \\
\hline Abund. & 193 & 321 & 80 & 384 & 291 & 195 & 191 & 159 & $227(35)$ \\
\hline Biomass & 12.1 & 19.2 & 4.3 & 29.1 & 16.9 & 9.7 & 10.7 & 7.6 & $13.7(2.78)$ \\
\hline \multicolumn{10}{|l|}{ Ciliates } \\
\hline ESD & 21.6 & 25.4 & 18.8 & 23.1 & 14.8 & 15.0 & 17.3 & 19.6 & $19.51(0.62)$ \\
\hline Abund. & 0.8 & 0.6 & 1.9 & 9.1 & 4.4 & 3.4 & 3.9 & 3.0 & $3.4(0.9)$ \\
\hline Biomass & 0.8 & 1.0 & 1.2 & 11.0 & 1.4 & 1.1 & 2.0 & 2.3 & $2.6(1.22)$ \\
\hline \multicolumn{10}{|l|}{ Dinoflag } \\
\hline ESD & 17.3 & 30.5 & 27.9 & 18.8 & 14.2 & 14.4 & 20.4 & 20.0 & $17.02(1.38)$ \\
\hline Abund. & 4.7 & 4.7 & 1.4 & 2.0 & 3.0 & 3.2 & 2.0 & 4.5 & $3.2(0.5)$ \\
\hline Biomass & 2.3 & 9.3 & 2.2 & 1.2 & 0.9 & 1.0 & 1.5 & 3.1 & $2.7(0.99)$ \\
\hline \multicolumn{10}{|l|}{ Single-Diat } \\
\hline ESD & 8.0 & 15.2 & 13.8 & 8.0 & 8.3 & 10.9 & 9.3 & 7.3 & $11.34(0.60)$ \\
\hline Abund. & 55 & 12 & 19 & 20 & 64 & 33 & 3 & 2 & $26(8)$ \\
\hline Biomass & 1.5 & 1.5 & 2.0 & 0.5 & 1.8 & 1.9 & 0.1 & 0,05 & $1.2(0.29)$ \\
\hline \multicolumn{10}{|l|}{ Chain-Diat } \\
\hline ESD & 12.6 & 19.7 & 20.6 & 1.4 & 13.3 & 17.4 & 11.7 & 9.1 & $16.43(0.66)$ \\
\hline Abund. & 27 & 2 & 25 & 18 & 463 & 254 & 0.1 & 2 & $99(60)$ \\
\hline Biomass & 2.2 & 0.6 & 6.7 & 1.1 & 43.0 & 45.0 & 0,01 & 0.1 & $12.3(6.95)$ \\
\hline Total biomass & 76.0 & 70.4 & 49.2 & 80.5 & 208.4 & 122.6 & 51.7 & 51.0 & \\
\hline
\end{tabular}


Table 3. Penilia avirostris. Weight-specific clearance rates $\left(\mathrm{ml} \mathrm{gg}^{-1} \mathrm{C} \mathrm{d}^{-1}\right.$; mean $\left.\pm \mathrm{SE}\right)$. Growth: values in experimental bottles higher than controls; 0: no significant ingestion; HetBact: heterotrophic bacteria; Proch: Prochlorococcus; Synec: Synechococcus; Flag: flagellates; Dinoflag: dinoflagellates; Single-Diat: single diatoms; Chain-Diat: chain-forming diatoms

\begin{tabular}{|c|c|c|c|c|c|c|c|c|}
\hline & Expt 1 & Expt 2 & Expt 3 & Expt 4 & Expt 5 & Expt 6 & Expt 7 & Expt 8 \\
\hline HetBact & 0 & 0 & 0 & 0 & Growth & Growth & 0 & Growth \\
\hline Proch & Growth & Growth & Growth & 0 & Growth & Growth & Growth & 0 \\
\hline Synec & Growth & 0 & 0 & 0 & Growth & 0 & 0 & 0 \\
\hline$<2 \mu \mathrm{m}$ Flag & $\begin{array}{c}41 \\
(4.4)\end{array}$ & $\begin{array}{c}10 \\
(0.8)\end{array}$ & $\begin{array}{c}15 \\
(0.2)\end{array}$ & $\begin{array}{c}13 \\
(0.5)\end{array}$ & $\begin{array}{c}19 \\
(1.2)\end{array}$ & $\begin{array}{c}32 \\
(1.9)\end{array}$ & $\begin{array}{c}34 \\
(1.7)\end{array}$ & $\begin{array}{c}17 \\
(1.0)\end{array}$ \\
\hline $2-5 \mu \mathrm{m}$ Flag & $\begin{array}{c}35 \\
(4.3)\end{array}$ & $\begin{array}{c}24 \\
(0.9)\end{array}$ & $\begin{array}{c}10 \\
(0.7)\end{array}$ & $\begin{array}{c}45 \\
(2.4)\end{array}$ & $\begin{array}{c}19 \\
(2.1)\end{array}$ & $\begin{array}{c}33 \\
(1.8)\end{array}$ & $\begin{array}{c}40 \\
(2.4)\end{array}$ & $\begin{array}{c}39 \\
(3.5)\end{array}$ \\
\hline$>5 \mu \mathrm{m}$ Flag & $\begin{array}{c}23 \\
(2.5)\end{array}$ & $\begin{array}{c}39 \\
(3.9)\end{array}$ & $\begin{array}{c}7 \\
(0.3)\end{array}$ & $\begin{array}{c}19 \\
(0.9)\end{array}$ & $\begin{array}{c}17 \\
(1.8)\end{array}$ & $\begin{array}{c}43 \\
(2.3)\end{array}$ & $\begin{array}{c}30 \\
(1.7)\end{array}$ & $\begin{array}{c}33 \\
(1.8)\end{array}$ \\
\hline Ciliates & 0 & 0 & 0 & 0 & $\begin{array}{c}10 \\
(0.5)\end{array}$ & $\begin{array}{c}31 \\
(4.3)\end{array}$ & 0 & $\begin{array}{c}8 \\
(0.8)\end{array}$ \\
\hline Dinoflag & $\begin{array}{c}31 \\
(3.3)\end{array}$ & $\begin{array}{c}38 \\
(3.4)\end{array}$ & 0 & $\begin{array}{c}25 \\
(1.9)\end{array}$ & $\begin{array}{c}25 \\
(1.3)\end{array}$ & $\begin{array}{c}44 \\
(3.5)\end{array}$ & $\begin{array}{c}24 \\
(3.1)\end{array}$ & $\begin{array}{c}31 \\
(1.2)\end{array}$ \\
\hline Single-Diat & 19 & $\begin{array}{c}0 \\
(2.0)\end{array}$ & 0 & 19 & $\begin{array}{c}2 \\
(3.2)\end{array}$ & $\begin{array}{c}54 \\
(0.44)\end{array}$ & $\begin{array}{c}45 \\
(5.4)\end{array}$ & $\begin{array}{c}0 \\
(9.8)\end{array}$ \\
\hline Chain-Diat & 0 & 0 & $\begin{array}{c}41 \\
(7.3)\end{array}$ & $\begin{array}{c}22 \\
(4.4)\end{array}$ & $\begin{array}{c}5 \\
(0.5)\end{array}$ & $\begin{array}{c}16 \\
(1.0)\end{array}$ & $\begin{array}{c}100 \\
(25.0)\end{array}$ & $\begin{array}{c}23 \\
(3.0)\end{array}$ \\
\hline
\end{tabular}

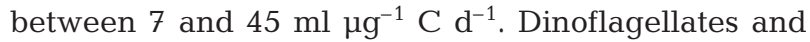
diatoms, although frequently representing an important contribution to the diet, were occasionally not grazed significantly by $P$. avirostris. Ciliates were rarely consumed by $P$. avirostris (in only 3 out of 8 experiments).

When relating the feeding rates of Penilia avirostris to food availability, the inclusion of bacteria in food availability bulk estimates might lead to erroneous conclusions, since they were not grazed on. From this point on, we excluded bacteria from calculations and defined edible food as that microbial biomass prone to being ingested by the cladoceran. Fig. 2 shows the composition of the edible food for $P$. avirostris in the experiments conducted. The initial edible microbial community was dominated in terms of biomass by flagellates, which comprised $>50 \%$ of the carbon in most of the experiments, with secondary contributions of dinoflagellates (Expt 2), diatoms (Expt 3, Expt 5 and Expt 6), or ciliates (Expt 4).

Ingestion rates in terms of daily rations ranged between 26 and $157 \%$ body $\mathrm{C} \mathrm{d}^{-1}$ and were positively related to total edible prey biomass (Fig. 3). No evidence of saturation was observed over the range of edible food biomass found during the studied period.

Regarding selectivity, we found significant differences among clearance rates for the different prey types within each experiment (1-way ANOVA, p < 0.05 ; Table 3), which is an indication of selection. Fig. 4 shows the selectivity coefficients $W^{\prime}$ as a function of the relative edible prey availability. No clear recurrent pattern was identified. A positive linear relationship is suggested in Expt 2, Expt 3 and Expt 8, whereas a negative relationship seems to appear in Expt 6. In other experiments no trend was observed (Expt 1, Expt 4, Expt 5 and Expt 7). A more intriguing result of this analysis, however, is that Penilia avi-

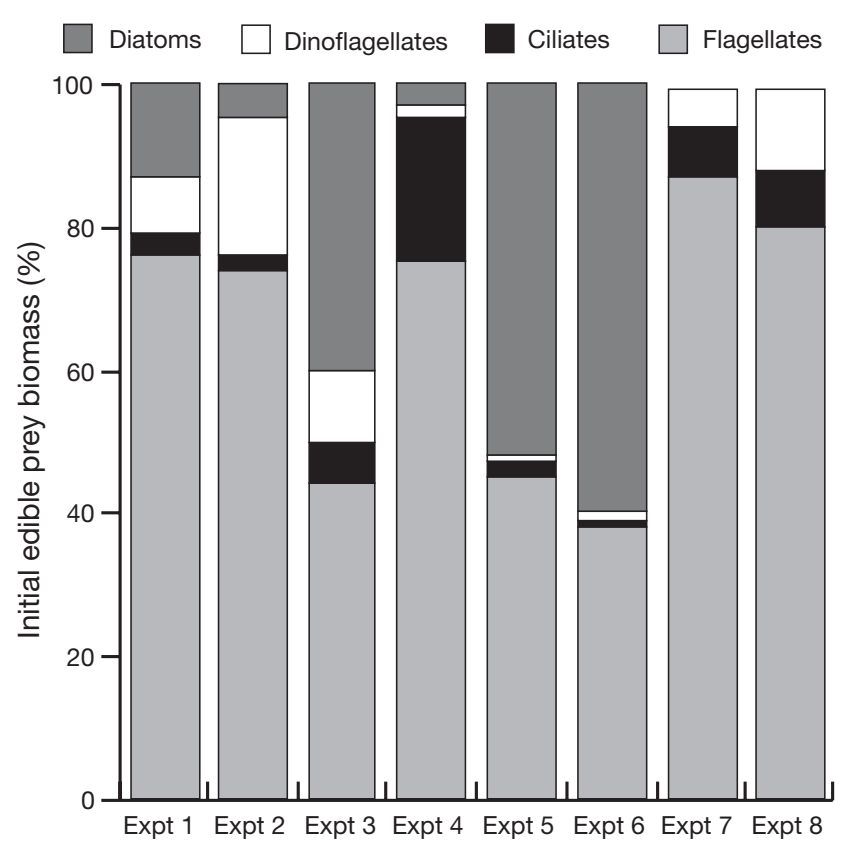

Fig. 2. Biomass contribution (as \%) of the different microbial groups considered (excluding the bacterioplankton), at the beginning of the experiments 


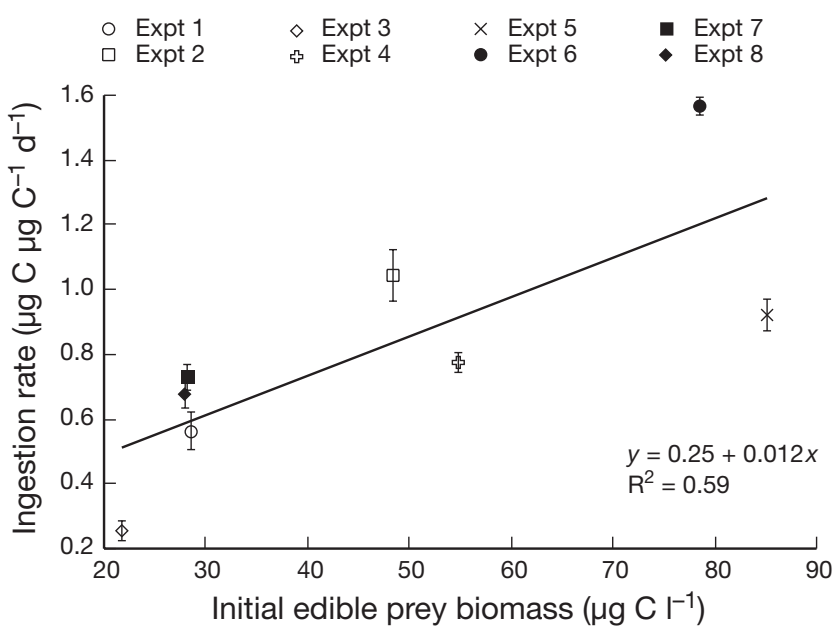

Fig. 3. Penilia avirostris. Relationship between ingestion rates and initial edible prey biomass. Error bars represent $\pm 1 \mathrm{SE}$

rostris, in spite of being typically considered a passive filter feeder, displayed variability in prey preference among experiments, independent of prey type and also independent of prey contribution to available biomass. For instance, if we consider a particular prey type like the 2 to $5 \mu \mathrm{m}$ flagellates, in 3 out of 8 experiments they constitute the preferred prey $\left(W^{\prime}=1\right)$, whereas in the rest of experiments they show medium ( $W^{\prime}$ between 0.6 and 0.8 ), or very low preference $\left(W^{\prime}\right.$ between 0.2 and 0.4 ), independent of their relative contribution to food availability (Fig. 4). There does not seem to be dependence on the initial food composition either, as can be seen by simply comparing the patterns in $W^{\prime}$ in the selectivity graphs for Expt 1, Expt 3, Expt 7 and Expt 8 (Fig. 4), all conducted at a similar initial food concentration.

\section{DISCUSSION}

\section{Lower prey size threshold in Penilia avirostris}

This study is one of the few to illustrate the feeding ecology of the marine cladoceran Penilia avirostris under natural dietary conditions, thus estimating the grazing of $P$. avirostris confronted with a wide spectrum of natural microbial prey. The clearance rates determined in the present study lie within the same range of values as in previous reports of $P$. avirostris feeding on heterotrophic flagellates (34 to $96 \mathrm{ml} \mathrm{ind.}{ }^{-1}$ $\mathrm{d}^{-1}$; Turner et al. 1988), diatoms (14 to $40 \mathrm{ml}$ ind..$^{-1} \mathrm{~d}^{-1}$; Turner et al. 1988), the Haptophyciae Isochrysis galbana (4 to $24 \mathrm{ml}$ ind. ${ }^{-1} \mathrm{~d}^{-1}$; Paffenhöfer \& Orcutt 1986), ciliates (4 to $33 \mathrm{ml}$ ind. ${ }^{-1} \mathrm{~d}^{-1}$; Broglio et al. 2004), and on different components of the microbial community (20 to $30 \mathrm{ml}$ ind..$^{-1} \mathrm{~d}^{-1}$; Katechakis et al. 2004).
One of the intriguing and ecologically relevant questions about the feeding of Penilia avirostris is whether or not they are capable of grazing on bacterial and picoflagellate communities and therefore whether or not they directly impact the microbial loop, similar to their freshwater relative Daphnia. Daphnids are important consumers of natural bacteria and small flagellates (Jürgens 1994), their ability to feed on small particles being determined by the morphology of the filtering apparatus (mesh size of the filter; Lampert 1987, Gerritsen et al. 1988). Impacts on picoplanktonic communities of about $50 \%$ due to daphnids are frequent in freshwater planktonic food webs (Degans et al. 2002, Zollner et al. 2003).

In the case of Penilia avirostris, there has been controversy about its ability to feed on picoplankton. Some studies have suggested that bacteria could be an important source of carbon for this cladoceran (Pavlova 1967, Paffenhöfer \& Orcutt 1986, Lipej et al. 1997). However, Turner et al. (1988) concluded that this organism could ingest relatively large or clumped bacteria, but not natural bacterioplankton (of a smaller size). This latter conclusion agreed with the observations of Gore (1980), who reported preferential ingestion for $P$. avirostris on plastic beads $>1 \mu \mathrm{m}$. Our results confirm the observations made by Turner et al. (1988), showing that natural heterotrophic and phototrophic bacteria cannot be grazed by $P$. avirostris. However, our study also evidences that the gap for the lower prey size threshold is very narrow, because $<2 \mu \mathrm{m}$ flagellates were significantly consumed in all experiments (albeit, overall, at lower clearance rates). Hence, the threshold for the minimum prey size for $P$. avirostris seemed to fall between the size of Synechococcus $(1 \mu \mathrm{m})$ and the $<2 \mu \mathrm{m}$ flagellates. The disagreement between our results and the recent work of Katechakis $\&$ Stibor (2004), where no grazing on $<2.5 \mu$ m prey was observed, is probably due to the methodology used by those authors to preserve and quantify bacteria and small flagellate samples. Our conclusions are further confirmed by the observations of intrasetular distances (1 to $2 \mu \mathrm{m}$ ) under light microscopy for our Mediterranean Sea specimens, which are also in agreement with the $\leq 2 \mu \mathrm{m}$ values under scanning electron microscopy reported by Turner et al. (1988) for West Atlantic $P$. avirostris.

One might expect, however, that there would be genetic and ontogenetic differences in the intersetular gap, which could explain some of the variability observed and the discrepancies among studies reported. The fact that the intrasetular distance increases with body size in daphnids (Brendelberger \& Geller 1985) suggests that perhaps younger (smaller) Penilia avirostris than the individuals used in our experiments might extend their prey size spectrum to smaller items 

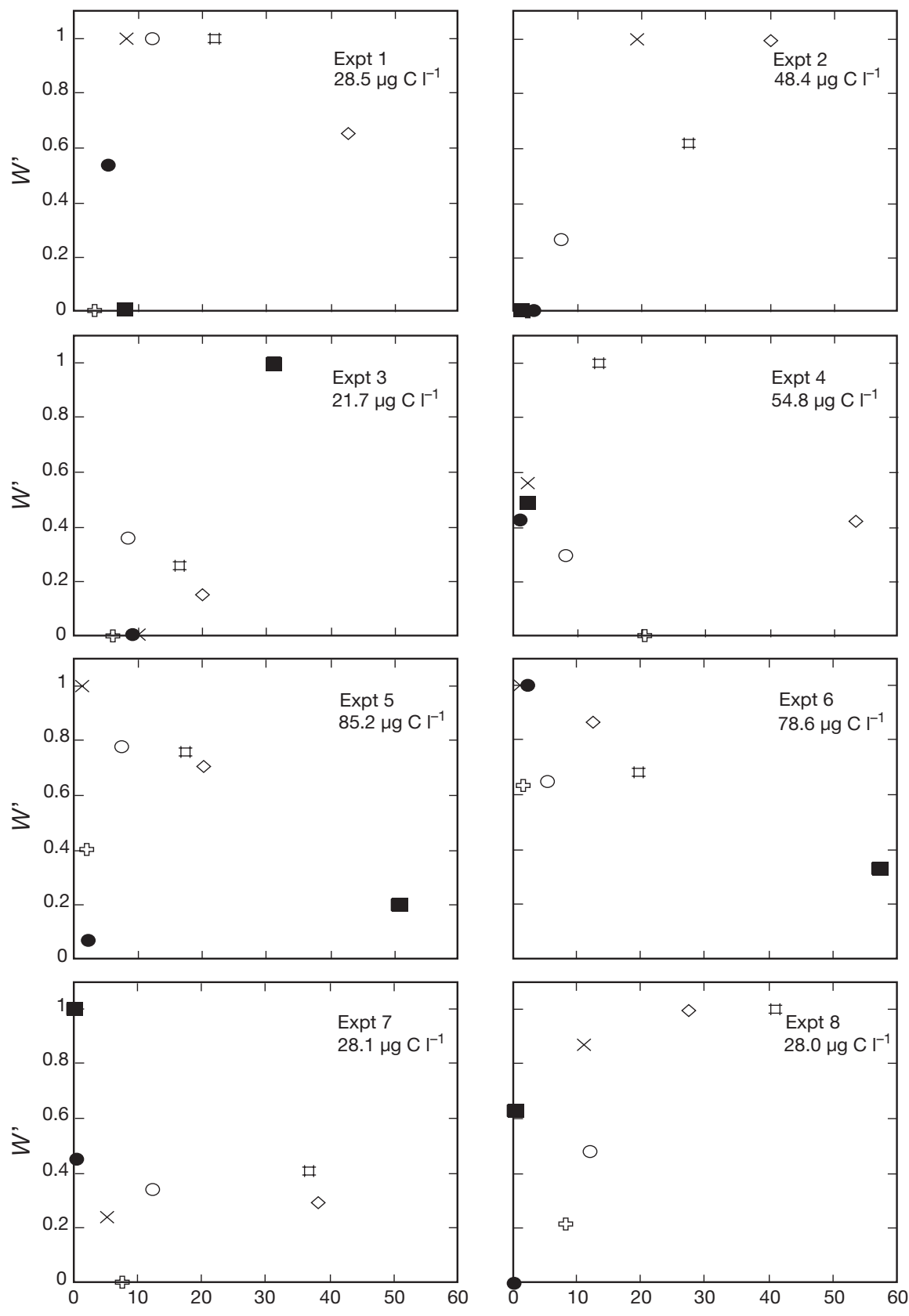

$\bigcirc<2 \mu \mathrm{m}$ Flag $\square 2-5 \mu \mathrm{m}$ Flag $\diamond>5 \mu \mathrm{m}$ Flag

\& Ciliates

$\times$ Dinoflag

- Single-diat

Chain-diat

Fig. 4. Penilia avirostris. Relationship between selectivity coefficient $W^{\prime}$ and prey contribution to initial edible biomass. Flag: flagellates; Dinoflag: dinoflagellates; Single-Diat: single diatoms; Chain-Diat: chain-forming diatoms

than the ones reported here. Other factors could also affect the lower prey size thresholds reported here. For example, changes in the hydrophobicity or electrostatic charges of the cell membrane (see 'Discussion') could affect the retention efficiency of the phyllopods. Due to the narrow gap for the lower prey size threshold observed, slight variations in the average size of the picoplanktonic fraction would result in variability in the clearance rates for $<2 \mu \mathrm{m}$ flagellates displayed by $P$. avirostris.

From an ecological point of view, the fact that Penilia avirostris, in contrast to Daphnia, cannot graze on heterotrophic and autotrophic bacteria indicates that this marine cladoceran cannot exert direct control on bac- 
terial production. But the ability of $P$. avirostris to feed on $<2 \mu \mathrm{m}$ flagellates leads to a trophic shortcut to the microbial loop very close to its base, resulting in more efficient transfer of energy towards the upper consumers compared to other marine zooplankters like copepods. In addition, $P$. avirostris may have indirect effects on bacterial production by grazing on the firstorder bacterivorous grazers $(<2 \mu \mathrm{m}$ flagellates).

\section{Prey selectivity by Penilia avirostris}

Penilia avirostris is a typical filter feeder that, similar to daphnids, is expected to largely exhibit passive and mechanical selection, wherein phyllopods form a mesh that retains particles (Paffenhöfer \& Orcutt 1986, Turner et al. 1988). Our observations seem to contradict, or at least do not fully confirm, such a theory.

In the present study we found relatively high clearance rates for flagellates, diatoms and dinoflagellates, whereas other prey were either not grazed upon because of their size (i.e. bacteria) or were grazed at low rates probably because of their ability to escape from feeding currents (ciliates; Jakobsen 2001, 2002). Our results partially contrast with those of Katechakis \& Stibor (2004) and Katechakis et al. (2004), who reported maximum ingestion rates by Penilia avirostris in the prey range between 15 and $70 \mu \mathrm{m}$ (equivalent to 6-28 $\mu \mathrm{m}$ ESD), corresponding to diatoms and dinoflagellates. However, the comparison is difficult because their investigation was conducted under very enriched conditions (up to $575 \mu \mathrm{g} \mathrm{C} \mathrm{l}^{-1}$ ), which were not representative of the natural microbial community where $P$. avirostris is found in the Mediterranean.

The 3 major dietary components in our study (flagellates, dinoflagellates and diatoms) alternated their role as preferred prey from experiment to experiment. Flagellates were the preferred prey on 6 occasions, and dinoflagellates and diatoms constituted the preferred prey, respectively, 4 and 3 times. It is also important to note that, often, there was $>1$ preferred prey for a given experiment. These variations in Penilia avirostris preferences are puzzling, and do not seem to be related to either prey size (for instance in Expt 1) or prey abundance (either in relative or absolute terms). It is possible that part of this preference for certain prey could be artifactual. For instance, the feeding activity of $P$. avirostris may break diatom chains apart, resulting in a higher selection for diatom chains compared to single cells (diatom chains disappear from incubation bottles, whereas single diatom cells increase their abundance). Trophic cascade effects could also mask real patterns. Feeding on both $<2$ and 2 to $5 \mu \mathrm{m}$ flagellates by $P$. avirostris may result in a release of grazing pressure on $<2 \mu \mathrm{m}$ flagellates by heterotrophic and mixotrophic 2 to $5 \mu \mathrm{m}$ flagellates, therefore masking the feeding of $P$. avirostris on those smallest flagellates. This hypothesis does not seem to hold, however, because in 5 out of the 8 experiments $W^{\prime}$ was the same for $<2$ and 2 to $5 \mu \mathrm{m}$ flagellates (Fig. 4). There is also a possibility that variations in $P$. avirostris body size among experiments could explain the variations in $W^{\prime}$ patterns. However, we explored this possibility by measuring the intrasetular distance of 2 animals from each experiment and found no difference. Changes in surface properties, such as hydrophobicity or the electrostatic charge of the cell membranes of both prey and cladoceran phyllopods, have also been considered plausible explanations for such changes in selectivity (Lampert 1987, Vanderploeg 1994).

Besides these hypothetical explanations for our results, there is evidence in daphnids that prey-selectivity patterns can be modified by the individual to some extent, as a function of size and quality. Vanderploeg (1994) reviewed such particle-selection mechanisms in freshwater cladocerans. Very large particles (e.g. filamentous algae) can be rejected by the abdominal claw or just by decreasing the carapace gap. Particles can be rejected even when contained in boluses. Further evidence is given by Lampert \& Brendelberger (1996), who reported that Daphnia can adjust the area of the filter screens and the appendage beat rate as a function of food concentration. The application of these behaviourally driven mechanisms of prey selection in the closely related Penilia avirostris seems plausible. In fact, Turner et al. (1988) observed that P. avirostris mostly ingested small heterotrophic flagellates ( 2 to $5 \mu \mathrm{m}$ ) and diatoms (4 to $12 \mu \mathrm{m})$, but was unable to graze upon the intermediate-sized Pseudoisochrysis paradoxa (5 to $6 \mu \mathrm{m})$. Paradoxically, Paffenhöfer \& Orcutt (1986) reported ingestion of the similarly sized Isochrysis galbana. Therefore, we feel that the variability in prey preference observed in our experiments reflect true changes in selectivity by $P$. avirostris, although the mechanisms underneath are not fully clear.

\section{Feeding performance of Penilia avirostris}

In the present study, Penilia avirostris' maximal daily food rations $\left(157 \%\right.$ body $\left.\mathrm{C} \mathrm{d}^{-1}\right)$ were higher than those reported previously (Pavlova 1967, Paffenhöfer \& Orcutt 1986), but similar to the maximal value (151\%) reported by Broglio et al. (2004) at food concentrations (phytoplankton and ciliate) of $125 \mu \mathrm{g} \mathrm{C}^{-1}$. Our results also agree with estimates for the freshwater cladoceran Daphnia (52 to $115 \%$ body $\mathrm{C} \mathrm{d}^{-1}$, Burns \& Schallenberg 2001; 100 to $157 \%$ body $\mathrm{C} \mathrm{d}^{-1}$, DeMott et al. $1998 ; 148$ to $312 \%$ body $\mathrm{C} \mathrm{d}^{-1}$, Sterner et al. 1993). More notable is the efficient performance of 
Table 4. Comparison of daily food rations $\left(D R, \%\right.$ body $\left.\mathrm{C} \mathrm{d}^{-1}\right)$

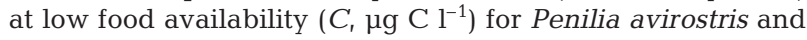
other zooplankters

\begin{tabular}{|c|c|c|c|c|c|c|c|}
\hline \multicolumn{2}{|c|}{$\begin{array}{l}\text { Penilia } \\
\text { avirostris }^{\mathrm{a}}\end{array}$} & \multicolumn{2}{|c|}{$\begin{array}{l}\text { Oikopleura } \\
\text { dioica }^{\mathrm{b}}\end{array}$} & \multicolumn{2}{|c|}{$\begin{array}{l}\text { Oikopleura } \\
\text { dioica }^{\mathrm{c}}\end{array}$} & \multicolumn{2}{|c|}{$\begin{array}{l}\text { Calanoid } \\
\text { copepods }^{\mathrm{d}}\end{array}$} \\
\hline$C$ & $D R$ & C & $D R$ & C & $D R$ & C & $D R$ \\
\hline 22 & 26 & 80 & 131 & 40 & 87 & $20-40$ & 17 \\
\hline 28 & 73 & 320 & 214 & 80 & 198 & $40-70$ & 24 \\
\hline 28 & 68 & 481 & 281 & 150 & 347 & $70-100$ & 27 \\
\hline 29 & 56 & 641 & 88 & & & & \\
\hline 48 & 104 & 1602 & 97 & & & & \\
\hline 55 & 78 & & & & & & \\
\hline 79 & 157 & & & & & & \\
\hline 85 & 92 & & & & & & \\
\hline \multicolumn{8}{|c|}{$\begin{array}{l}{ }^{a} \text { Present study, field data } \\
{ }^{b} \text { Acuña \& Kiefer (2000), laboratory experiments } \\
{ }^{c} \text { Selander \& Tiselius (2003), laboratory experiments } \\
\text { dE. Saiz \& A. Calbet (unpubl. data), field data obtained from } \\
\text { a review of literature }\end{array}$} \\
\hline
\end{tabular}

P. avirostris at the low food concentrations that characterise its natural habitat, with daily rations up to $73 \%$ at concentrations $<30 \mu \mathrm{g} \mathrm{C}^{-1}$. This high efficiency of $P$. avirostris under oligotrophic conditions may explain its fast blooming and dominance in coastal zooplankton during the stratification period, where oligotrophic conditions prevail. However, it poses the question why $P$. avirostris does not spread to the oligotrophic openocean waters. Very likely the dependence on resting embryos in the sediment for the successful development of a new seasonal cohort in the following year restricts its habitat to shelf waters. This geographic restriction also constrains $P$. avirostris on a seasonal basis to the stratification period, because the richer conditions of shelf waters during the rest of the year may have deleterious effects (clogging) on their filterfeeding appendages (Paffenhofer \& Orcutt 1986). At similarly low food concentrations, the daily food rations of copepods are $<30 \%$ body $\mathrm{C} \mathrm{d}^{-1}$ (Table 4). Copepods are less efficient feeding on small prey $(<5 \mu \mathrm{m}$, Bergreen et al. 1988), which are the major contributors to seston biomass under such oligotrophic conditions (Agawin et al. 2000). We can compare P. avirostris to another important filter feeder in coastal waters as well. The appendicularians perform similarly well at equivalent food concentrations (Table 4), with the peculiarity that they also can do well in richer waters and ingest bacterioplankton (Scheinberg et al. 2005). Having a similar or even better feeding performance than $P$. avirostris, it is not clear why appendicularians do not dominate summer coastal waters in the NW Mediterranean (Calbet et al. 2001).

In this study we have characterised the feeding ecology of Penilia avirostris, the only filter-feeding cladoceran in the marine environment. $P$. avirostris ingests a broad spectrum of prey types, their diet being constituted mainly of flagellates, dinoflagellates and diatoms. In contrast to a typical, passive filter feeder, $P$. avirostris shows behaviourally driven plasticity in their prey selection by mechanisms not fully understood. The species seems to be optimally adapted to oligotrophic environments, exhibiting relatively high daily rations compared to the most common marine zooplankters (copepods).

Acknowledgements. This work was supported by a PhD fellowship from the Spanish Government to D.A., by the Spanish CICYT Projects REN2001-1693 and CTM2004-02575/MAR, and by the Ramón y Cajal Program of the Ministry of Education and Science of Spain. The authors also thank the captain and crew at Masnou Harbour, and Pepito and Ramon at Olimpic Harbour in Barcelona, who kindly provided facilities and access to the sea. Finally, we thank Belén Aguilera for technical assistance and the reviewers for their valuable comments.

\section{LITERATURE CITED}

Acuña JL, Kiefer M (2000) Functional response of the appendicularian Oikopleura dioica. Limnol Oceanogr 45(3): 608-618

Agawin N, Duarte CM, Agustí S (2000) Nutrient and temperature control of the contribution of picoplankton to phytoplankton biomass and production. Limnol Oceanogr 45: 591-600

Båmstedt U, Gifford DJ, Irigoien X, Atkinson A, Roman M, Harris RP (2000) Feeding, Chapter 8. In: Wiebe PH, Lenz J, Skjoldal HR, Huntley M (eds) ICES zooplankton methodology manual. Academic Press, London, p 297-399

Berggreen U, Hansen B, Kiørboe T (1988) Food size spectra, ingestion and growth of the copepod Acartia tonsa during development: implications for determination of copepod production. Mar Biol 99:341-352

Børsheim KY, Bratbak G (1987) Cell volume to cell carbon conversion factors for a bacterivorous Monas sp. enriched from seawater. Mar Ecol Prog Ser 36:171-175

Brendelberger H, Geller W (1985) Variability of filter structures in eight Daphnia species: mesh sizes and filtering areas. J Plankton Res 7:473-486

Broglio E, Saiz E, Calbet A, Trepat I, Alcaraz M (2004) Trophic impact and prey selection by crustacean zooplankton on the microbial communities of an oligotrophic coastal area (NW Mediterranean Sea). Aquat Microb Ecol 35:65-78

Burns CW, Schallenberg M (2001) Calanoid copepods versus cladocerans: effects on protozoa in lakes of different trophic status. Limnol Oceanogr 46:1558-1565

Calbet A, Saiz E (2005) The ciliate-copepod link in marine ecosystems. Aquat Microb Ecol 38:157-167

Calbet A, Garrido S, Saiz E, Alcaraz M, Duarte M (2001) Annual zooplankton succession in coastal NW Mediterranean waters: the importance of the smaller size fractions. J Plankton Res 23:319-331

Cebrián J, Duarte CM, Pascual J (1996) Marine climate on the Costa Brava (northwestern Mediterranean). Pub Espec Inst Esp Oceanogr 22:9-21

Degans H, Zollner E, Van der Gucht K, De Meester L, Jurgens K (2002) Rapid Daphnia-mediated changes in microbial community structure: an experimental study. FEMS Microbiol Ecol 42(1):137-149 
Della Croce N (1964) Distribuzione e biologia del cladocero marino Penilia avirostris Dana. Bull Inst Oceanogr 62:1-18

DeMott WR, Gulati RD, Siewertsen K (1998) Effects of phosphorus-deficient diets on the carbon and phosphorus balance of Daphnia magna. Limnol Oceanogr 43:1147-1161

Egloff DA, Fofonoff PW, Onbé T (1997) Reproductive biology of marine cladocerans. Adv Mar Biol 31:79-168

Frost BW (1972) Effects of size and concentration of food particles on the feeding behavior of the marine planktonic copepod Calanus pacificus. Limnol Oceanogr 17:805-815

Gasol JM, del Giorgio PA (2000) Using flow cytometry for counting natural planktonic bacteria and understanding the structure of planktonic bacterial communities. Sci Mar 64(2):197-224

Gerritsen J, Porter KG, Strickler JR (1988) Not by sieving alone: observations of suspension feeding in Daphnia. Bull Mar Sci 43:366-376

González HE, Gieseckea R, Vargas CA, Pavez M and 5 others (2004) Carbon cycling through the pelagic foodweb in the northern Humboldt Current off Chile $\left(23^{\circ} \mathrm{S}\right)$. ICES J Mar Sci 61(4):572-584

Gore MA (1980) Feeding experiments on Penilia avirostris Dana (Cladocera: Crustacea). J Exp Mar Biol Ecol 44:253-260

Hsu JC (1981) Simultaneous confidence intervals for all distances from the 'best'. Ann Stat 9(5):1026-1034

Jakobsen HH (2001) Escape response of planktonic protists to fluid mechanical signals. Mar Ecol Prog Ser 124:67-78

Jakobsen HH (2002) Escape of protists in predator-generated feeding currents. Aquat Microb Ecol 26:271-281

Jürgens K (1994) Impact of Daphnia on planktonic microbial food webs: a review. Mar Microb Food Webs 8:295-324

Katechakis A, Stibor H (2004) Feeding selectivities of the marine cladocerans Penilia avirostris, Podon intermedius and Evadne nordmanni. Mar Biol 145:529-539

Katechakis A, Stibor H, Sommer U, Hansen T (2004) Feeding selectivities and food niche separation of Acartia clausi, Penilia avirostris (Crustacea) and Doliolum denticulatum (Thaliacea) in Blanes Bay (Catalan Sea, NW Mediterranean). J Plankton Res 26:589-603

Kim SW, Onbé T, Yoon YH (1989) Feeding habits of marine cladocerans in the Inland Sea of Japan. Mar Biol 100: 313-318

Lampert W (1987) Feeding and nutrition in Daphnia. In: Peters RHD, Bernardi R (eds) Daphnia. Memorie dell' Istituto Italiano di Idrobiologia Dr. Marco de Marchi. Consiglio Nazionale Delle Ricerche Verbania Pallanza, p 143-192

Lampert W, Brendelberger H (1996) Strategies of phenotypic low-food adaptation in Daphnia: filter screens, mesh sizes, and appendage beat rates. Limnol Oceanogr 41(2): 216-223

Lipej L, Mozetic P, Turk V, Malej A (1997) The trophic role of the marine cladoceran Penilia avirostris in the Gulf of Trieste. Hydrobiologia 360:197-203

López-Urrutia A, Irigoien X, Acuña JL, Harris R (2003) In situ feeding physiology and grazing impact of the appendicularian community in temperate waters. Mar Ecol Prog Ser 252:125-141

Maar M, Nielsen TG, Gooding S, Tönnensson K and 5 others (2004) Trophodynamic function of copepods, appendicularians and protozooplankton in the late summer zooplankton community in the Skagerrak. Mar Biol 144: 917-933
Marazzo A, Valentin JL (2001) Spatial and temporal variations of Penilia avirostris and Evadne tergestina (Crustacea, Branchiopoda) in a tropical bay, Brazil. Hydrobiologia 445:133-139

Menden-Deuer S, Lessard EJ (2000) Carbon to volume relationships for dinoflagellates, diatoms, and other protist plankton. Limnol Oceanogr 45:569-579

Norland S (1993) The relationship between biomass and volume of bacteria. In: Kemp PF, Sherr BF, Sherr EB, Cole JJ (eds) Handbook of methods in aquatic microbial ecology. Lewis Publisher, Boca Raton, FL, p 303-307

Onbé T (1985) Seasonal fluctuations in the abundance of populations of marine cladocerans and their resting eggs in the Inland Sea of Japan. Mar Biol 87:83-88

Onbé T, Ikeda T (1995) Marine cladocerans in Toyama Bay, southern Japan Sea: seasonal occurrence and day-night vertical distributions. J Plankton Res 17(3):595-609

Paffenhöfer GA, Orcutt JD (1986) Feeding, growth and food conversion of the marine cladoceran Penilia avirostris. J Plankton Res 8:741-754

Pavlova EG (1967) Food requirements of the Black Sea cladoceran Penilia avirostris Dana, and how they are met. Fish Res Board Can Trans Ser 908:31

Porter KG, Feig YS (1980) The use of DAPI for identifying and counting aquatic microflora. Limnol Oceanogr 25:943-948

Putt M, Stoecker DK (1989) An experimentally determined carbon:volume ratio for marine 'oligotrichous' ciliates from estuarine and coastal waters. Limnol Oceanogr 34: 1097-1103

Scheinberg RD, Landry MR, Calbet A (2005) Grazing of two common appendicularians on the natural prey assemblage of a tropical coastal ecosystem. Mar Ecol Prog Ser 294:201-212

Selander E, Tiselius P (2003) Effects of food concentration on the behavior of Oikopleura dioica. Mar Biol 142:263-270

Sterner RW, Hagemeier DD, Smith WL, Smith RF (1993) Phytoplankton nutrient limitation and food quality for Daphnia. Limnol Oceanogr 38:857-871

Turner JT, Tester PA, Ferguson RL (1988) The marine cladoceran Penilia avirostris and the 'microbial loop' of pelagic food webs. Limnol Oceanogr 33:245-255

Turner JT, Hopcroft RR, Lincoln JA, Huestis CS, Tester PA, Roff JC (1998) Zooplankton feeding ecology: grazing by marine copepods and cladocerans upon phytoplankton and cyanobacteria from Kingston Harbour, Jamaica. PSZN I: Mar Ecol 19:195-208

Uye S (1982) Length-weight relationships of important zooplankton from the Inland Sea of Japan. J Oceanogr Soc Jpn 38:149-158

Valiela I (1995) Marine ecological processes. Springer-Verlag, New York

Vanderploeg HA (1994) Zooplankton particle selection and feeding mechanisms. In: Wotton RS (ed) The biology of particles in aquatic systems. Lewis Publisher, New York, p 205-234

Waterbury JB, Watson SW, Valois FW, Franks DG (1986) Biological and ecological characterization of the marine unicellular cyanobacterium Synechococcus. Can Bull Fish Aquat Sci 214:71-120

Zollner E, Santer B, Boersma M, Hoppe HG, Jurgens K (2003) Cascading predation effects of Daphnia and copepods on microbial food web components. Freshw Biol 48(12): $2174-2193$

Submitted: July 11, 2005; Accepted: December 5, 2005

Proofs received from author(s): May 31, 2006 